\title{
Innovations in Value-Addition of Agricultural By-Products in Uganda
}

\author{
Denis Nsubuga ${ }^{1}$, Noble Banadda ${ }^{1,2}$, Nicholas Kiggundu ${ }^{1 *}$ \\ ${ }^{1}$ Department of Agricultural and Biosystems Engineering, Makerere University, Kampala, Uganda \\ ${ }^{2}$ Department of Agricultural and Biosystems Engineering, 1340 Elings Hall, Ames, Iowa, USA \\ Email: ^kiggundu@caes.mak.ac.ug
}

How to cite this paper: Nsubuga, D., Banadda, N. and Kiggundu, N. (2019) Innovations in Value-Addition of Agricultural By-Products in Uganda. Journal of Environmental Protection, 10, 1493-1506. https://doi.org/10.4236/jep.2019.1011089

Received: September 9, 2019

Accepted: November 11, 2019

Published: November 14, 2019

Copyright $\odot 2019$ by author(s) and Scientific Research Publishing Inc. This work is licensed under the Creative Commons Attribution International License (CC BY 4.0).

http://creativecommons.org/licenses/by/4.0/

\begin{abstract}
The purpose of this review was to profile the existing innovations in the value addition of agricultural by-products and suggest innovations that could yield more value-added products from the available agricultural by-products in Uganda. These by-products were from crops, livestock, fish and forestry sub-sectors. The review indicated 7.8 million tons from the crops' subsector, 6.69 million skins and hides, 2280 million tons of cow dung and 390,550 tons of chicken dung from the livestock subsector, 36,000 tons from the fish subsector and 440,000 $\mathrm{m}^{3}$ of sawdust and offcuts from the forestry sub-sector. Current innovations in value-addition of agricultural by-products included the making of briquettes, organic fertilizers, biogas, biochar, pellets and organic pesticides from the crop subsector. Cow dung from the livestock is used for plastering walls of houses, used as fertilizer and used for the production of biogas. Chicken droppings are as well used as fertilizer and for production of biogas. Fish frames and skins are mainly consumed in smoked form whereas trimmings are usually rolled into fish balls and then fried for people to eat while the fats are used for frying the fish balls. Sawdust has been mixed with cement to make wood-cement composite bricks that reduce the overall weight of the building. It is also being used as feed in the Indigenous Micro-Organisms (IMO) technology in the production of pigs. Proposed innovations include the use of bones to produce soft tissue, buttons, knife handles and bone meal. Blood can be used in making adhesives and fertilizers while fish oil is a major dietary source of long chain omega-3 polyunsaturated fatty acids and so can be utilized to enrich different food products.
\end{abstract}

\section{Keywords}

Value Addition, Agricultural Waste, By-Products, Innovations in Agriculture, Agricultural Value Chains 


\section{Introduction}

Uganda is considered to have an agricultural based economy and a food basket of the East African region, given its ability to produce a variety of foods. This agricultural sector comprises crop production, livestock, forestry and fishing sub-sectors. More than $80 \%$ of the total Ugandan population depends on agriculture for their daily living [1]. Hence value addition of agricultural products is very key in raising their standards of living for majority of Ugandans. Agriculture generates a number of by-products which when added value to can produce other useful products that are environmentally friendly with a higher market value.

Agricultural by-products are referred as agricultural wastes [2] which in most cases are just disposed-off with no value added. Such waste pollutes the environment and its accumulation has negative effects on the humans around it. The effect of poor agricultural waste disposal on the environment depends not only on the amounts generated but also on the disposal methods used [3]. Sanitary landfill has become an unsustainable disposal method of waste disposal due to land scarcity despite its being the commonest method used [4]. Consequently, some solid waste is left to decompose in the markets and processing factories. This is usually because of an inability by the concerned authorities to manage such waste appropriately.

In Uganda, Kampala Capital City Authority with a monthly waste collection of 5000 tons, has one landfill located in a residential area with some farming and is already causing environmental concerns [5] and public health issues. People living near the landfill site have always complained of this landfill making their place inhabitable and their land has lost value [5]. Research indicates that odour pollution contributes highly to uncomforting livestock farmers in Kampala [2]. Like in many undeveloped countries, another agricultural waste disposal method in Uganda is burning. Different pollutants are released including smoke carbon/particles, nitrous oxide, nitrogen dioxide and carbon monoxide when agricultural wastes are burnt [6]. When the pollutants are released into the atmosphere, they cause the formation of acid rains (nitric acid) and depletion of the ozone. This has imposed a risk to human and ecological health.

However, if managed well, these agricultural wastes can be considered an important raw material for making other useful products that are environmentally friendly and of higher economic value. The purpose of this review paper is to profile the available innovations in value addition of agricultural by-products in Uganda.

\section{Agricultural By-Products and Innovations in Their Value Addition in Uganda}

\subsection{By-Products from Agricultural Production and Processing}

Agricultural by-products produced before and after processing include farm and market residues and by-products from processing plants. Farm by-products include mainly biomass which is sometimes dried and stored as forage supplement 
for ruminants. There is also biomass from wood when trees are cut down to produce timber. Other by-products include; animal dung and urine from cattle and goats, droppings and feathers from poultry. By-products from processing plants highly depend on the raw material being processed and kind of processing plant. Such plants include; diary processing factories, maize mills, fish processing factories, fruit processing factories, meat slaughtering and processing factories, sugar factories, tea factories, coffee factories, cotton factories amongst others. The processing by-products can be categorized into, hides, hoofs, heads, offal, bones, blood, fat and trimmings from animals; milk sludge, and curd from dairy factories; peelings, stems, seeds, shells, trimmings, residues from fruits factories and offal, bones, scales and others from the fish factories [7].

\section{Crop products}

Uganda produces about 1.4 million tons of agro-processing vegetal waste and bagasse [8] and 6,449,111 tons of farm level crop residues annually [9]. Unfortunately, most of this waste is not used but just disposed into the landfill. In other cases, these wastes are disposed by burning which is not environmentally acceptable due to its associated negative consequences. Besides the mango wastes and other vegetal wastes, it is estimated that 280,000 tons coffee husks are generated from coffee hullers in Uganda annually [10]. Another important agricultural by-product is the cotton seeds which are produced alongside cotton wool. According to [11] the sugar production recorded in Uganda in 2009 was 287,387 tons which were a rise of $20 \%$ over 2008 production. The major by-products from sugar factories are; bagasse, molasses and Filter press cake [12]. According to [13] it was reported that the production of paddy rice increased from about 120,000 tons in 2002 to more than 220,000 tons in 2011 and that on average, $20 \%$ of the paddy rice is husk implying that 44,000 tons of husks were produced in 2011 alone.

\section{Livestock products}

Cattle and Chicken are considered for this review because they are the commonest amongst the Ugandan farmers in the livestock sub-sector. The national cattle herd is about 11.4 million cattle [14]. Most of it comes from the western and eastern regions of the country. With a few from the central region, northern region and the Karamoja sub-region. By-products from cattle include cow dung, urine, hides, hoofs, heads, and offal, bones, and blood, fat and meat trimmings. Cow dung is the main by-product from the livestock industry [15] followed by skins and hides. An average cow in Uganda produces about 20 tons of dung per annum [16] implying a total cow dung production of 2,280 million tons annually. The total annual production of skins and hides is 6.69 million pieces with 1.94 million hides, 1.02 million sheep skins and 3.73 million goat skins [17]. The nation chicken flock for Uganda was estimated to be 37.4 million with eastern region having the highest number of 10.7 million birds and the western region with the least number of 7.2 million birds [14]. Estimates of the chicken dung excreted by 1000 birds per day are $120 \mathrm{~kg}$ for layers and $80 \mathrm{~kg}$ for broilers [18] implying an average production of about $0.1 \mathrm{~kg}$ per bird per day giving an an- 
nual total production of over 390,550 tons of chicken dung.

\section{Fish products}

Fillet constitutes about $37 \%-40 \%$ of the total fish and the remaining $60 \%$ $63 \%$ is basically by-products which in most cases have low commercial value [19]. The major type of fish being dealt with in Uganda is Nile perch because of its availability and high demand in the export market. Uganda produces over 36,000 tons of fish by-products annually [20] with several distribution channels for fish by-products as shown in Figure 1. Nile Perch skins are being processed into leather at an on-site tannery on a pilot scale by Gomba Fishing Industries, a fish processing plant in Uganda on the shores of Lake Victoria. It is hoped that this leather may be sold into the international fashion world in the future.

\section{Forestry products}

Uganda's forested and woodlands were estimated to approximately 10.8 million ha of land in 1890 [22]. By 1990, the total forest cover and woodlands had reduced to 4.9 million hectares which have further reduced to 1.8 million hectares in 2015 [23]. This further reduction has translated into a loss of 3.1 million hectares in 25 years or an average annual forest loss of about 122,000 hectares. According to [23], the biggest average annual forest loss was about 256,000 hectares between 2005 and 2010 during which 1,286,753 were lost in just 5 years. During the period of 2010 to 2015, a total of about 463,000 hectares were lost. Uganda grows several tree species that have the capacity to avail whatever category of timber that the market may require. The common hard wood species include Chlorophora excelsa, Khaya anthothesa, Entandroprhagma cylindricum, Entandrophragma util and others. Most of trees today are grown for timber and production of pole to be used for construction. It is estimated that about 500,000 $\mathrm{m}^{3}$ of wood is consumed as sawn timber and 2,000,000 $\mathrm{m}^{3}$ of round wood annually [24]. The wood utilization industry in Uganda is characterized by poor harvesting and processing methods and limited value addition. The methods include use of pit-sawmills and the chain sawmills. Most of these saw mills mobile in nature with an average recovery of $45 \%$ [25] hence more than $50 \%$ of the wood is lost as waste. Wood by-products or wastes include chippings, slabs, off-cuts, sawdust and shavings. Sawdust is main by-product from wood. A tour of saw milling sites in Uganda reveals that there are a large heap of sawdust as shown in Figure 2 which is usually burnt as a way of disposing. However, burning is largely discouraged by environmentalists as a means of waste disposal method. Saw dust is the major by-product from wood as shown in Figure 2. The total sawmilling residues (saw dust and off cuts) are estimated to be $440,000 \mathrm{~m}^{3}$ [9].

\subsection{Current Innovations of Agricultural By-Products}

The final disposal of agricultural waste/by-products is usually an environmental problem [26]. This has raised concerns amongst scientists in the country and several innovative solutions have been provided to make different value-added products from these agricultural wastes. 


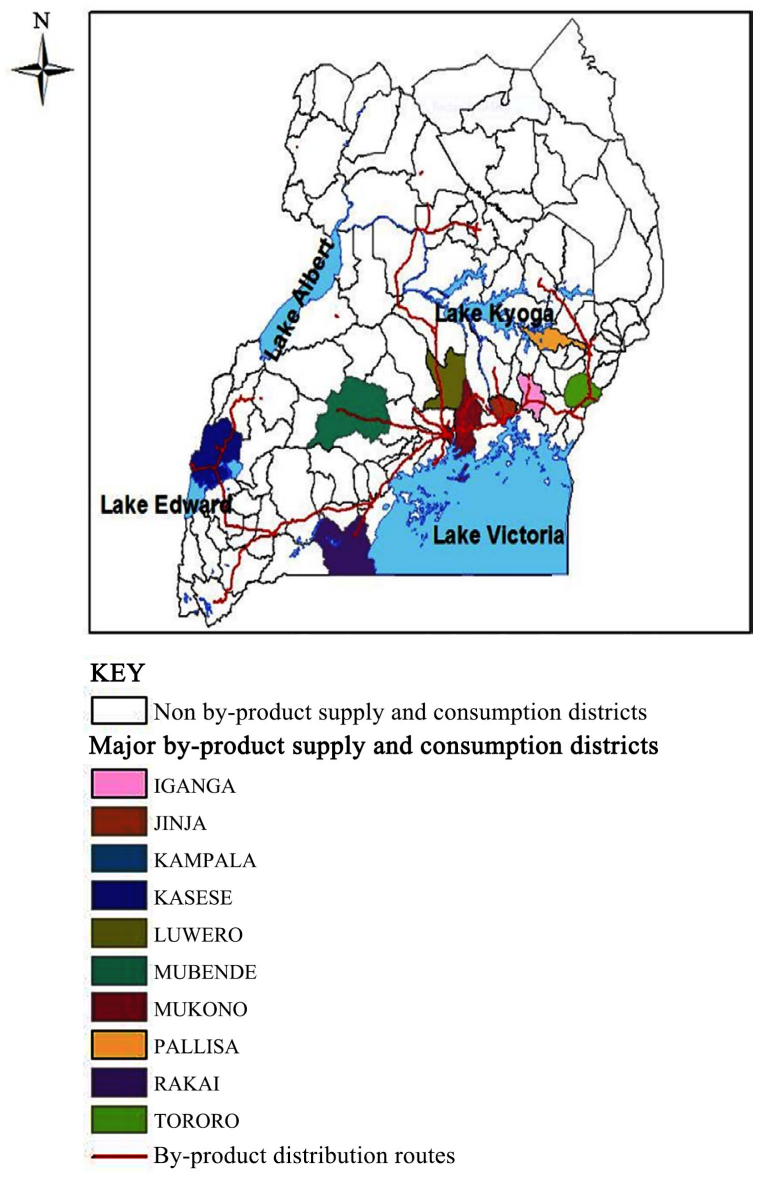

Figure 1. Fish by-product distribution areas of Uganda [21].

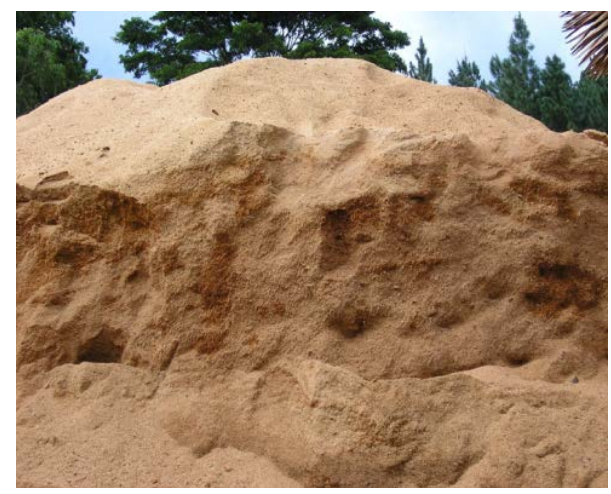

Figure 2. Heap of saw dust Source: [25].

\subsubsection{Innovations to Crop and Industrial Wastes/By-Products}

Different innovations have suggested making briquettes, fertilizers, biogas, biochar, biodiesel, pellets and organic pesticides from these agricultural wastes. According to [27], Mango waste such as seed covers are potential raw materials for making briquettes and the quality produced when seed covers are used is highly influenced by the binder types used with starch being the best binder recommended. Coffee husks are another form of fuel in Uganda though its use is not widespread. This is because in loose form, coffee husks burn with low efficiency 
and high rates of pollution [28]. Also, loose coffee husks are bulky and so difficult to handle, transport and store. Therefore, biomass densification which is defined as application of mechanical pressure to loose biomass to convert it into a high density solid material [29] is employed to reduce these limitations. According to [28], it is possible to make long-lasting briquettes using molasses as a binder. The briquettes have been used to provide fuel for cooking at home which reduces the over reliance on charcoal and wood. According to [10], it was noted that Hima cement factory uses coffee husks on a large scale (24 ton/day) in the calcination of lime and in addition, Uganda Clays Ltd and Kajjansi Clays use 140 and 100 tons of coffee husks every month respectively in their kilns. Coffee husks are also being poured on the floor of chicken houses to form a deep litter [30]. Fuel briquettes have also been made from agricultural and commercial residues other than from coffee husks and mango waste such as weeds, leaves, rice husks which are unique, yet well proven technology for an alternative energy source [31]. Edible Oil has been extracted from the cotton seed using the expeller-pressing method, coupled with chemical refining [32]. Besides the edible oil, cotton seed oil is a raw material in making soap industrially. Cotton seed cake, a by-product of cotton seed oil extraction, is used for making animal feeds.

Sugarcane by-products are being consumed by both humans and animals and they are good sources of renewable energy. Molasses are being used as binders for making of briquettes from coffee husks [28]. Bagasse is being utilized on a large scale by the major sugar industries which include Kakira Sugar Works, Sugar Corporation of Uganda Limited (SCOUL) and Kinyara Sugar Works in meeting their internal thermal energy and electric power [10]. This process is called cogeneration. About 3.35 tons of bagasse produces per ton of sugar. The filter cake is not of great concern in Uganda but according to [33], the filter can be used as a lime replacement in the agricultural sector although it is reported to have a lot of moisture content.

Maize residues have been used as a raw material in pyrolysis to produce biochar [34] and biodiesel [35]. Pyrolysis is the thermo-chemical conversion of biomass under limited supply of oxygen at temperatures ranging from $350^{\circ} \mathrm{C}$ to $700^{\circ} \mathrm{C}$ [36]. Products of pyrolysis include charcoal, biodiesel and biochar, the proportion of which varies with the temperature and time taken by the biomass material in the reactor [37]. In Uganda, research on biochar and biodiesel from maize residues is still at its infant stage but with promising results so far. Because biochar has a high porosity when it is mixed with the soil, it increases the general porosity and enhances distribution of micro pores in the soil [38]. Therefore, biochar technology has been found to be a feasible way of working around the problem of limited land while solving the problem of soil fertility [39].

Agricultural wastes in Uganda are being used as animal feeds and as fertilizers. According to [2], many small scale farmers in Kampala have increased the quantities of their milk by feeding animals with a number of agricultural wastes combined together and others have used this waste to add more nutrients to the soils. This has been done by applying organic manure and their crop yields have 
greatly improved, particularly vegetables and maize that fetch them more money.

About $70 \%$ of Ugandan farmers in the main farming districts grow matooke as a primary crop and over $50 \%$ depend on this crop for food and money [40]. However, $33 \%$ of each bunch of matooke peeled is organic waste [41]. According to [9], when organic waste is buried in pits under partially anaerobic conditions, it is broken down under low oxygen conditions to give off methane and carbon dioxide which is biogas. Hence the potential of matooke peels as a raw material for biogas production by anaerobic digestion has been a concern to scientists in Uganda. According to [42] fresh matooke peels have a higher $\mathrm{C} / \mathrm{N}$ ratio than the optimum range for anaerobic digestion and thus not suitable feedstock unless the $\mathrm{C} / \mathrm{N}$ ratio is adjusted. However, pretreatment of the matooke peels by storage under ambient condition for maximum four days, adjusts the $\mathrm{C} / \mathrm{N}$ ratio to the optimum range that favors anaerobic digestion without affecting other peel constituents important in aerobic digestion process [42]. Therefore, producing biogas using matooke peels has been found possible under these conditions. This biogas is being used to meet some of the farmers' cooking and lighting needs. Besides making biogas from banana peels, according to [43], banana waste biomass is a potential raw material for slow pyrolysis of wood vinegar and tar which are potential organic pesticides.

According to [44], the properties exhibited by the maize cob, particleboards could as well be used in low moisture conditions and in applications where low stresses are expected. Maize cob particleboards were found to be more prone to effects of moisture thus need to be laminated in case they are to have a long-life span. This is a good alternative use for maize cobs instead of the conventional use as fuel by most farmers.

According to [13], husks from the different varieties of rice in Uganda were characterized for bio-fuels and their techno-economic feasibility in gasification. Several techniques to convert rice husks into energy have been suggested. These include thermo-chemical, bio-chemical and physical-chemical conversion techniques [45]. The burning of rice husk under controlled conditions produces rice husk ash (RHA), which is used industrially as a raw material because of its high silica content. Rice husks generated in Uganda have an electricity generation potential of 15,310 MWh/year giving an annual diesel saving of $\$ 4,903,636$ and carbon dioxide saving of 14,045 $\mathrm{tCO}_{2}$ /year [13].

\subsubsection{Innovation for the Livestock By-Products}

In Uganda, cow dung is used as a construction material on wall finishing by plastering [46]. Cow dung is also used as a source of on farm manure [47] and a valuable source of plant nutrients to meet $\mathrm{N}, \mathrm{P}$ and $\mathrm{K}$ requirements in the country [48]. However, the dung quality has been found to be poor due to poor manure management practices. Cow dung has been discovered to improve the $\mathrm{pH}$ of acid soil [49] instead of using lime. It is also being used for improving the texture and the ability of the soil to absorb water. Besides, cow dung is a tradi- 
tional source for biogas production [50]. However, the co-digestion of cow dung with pig manure has been discovered to increase the yield of biogas compared to pure sample of either pig or cow dung and best results were achieved when the two were mixed in the ratio of 1:1 [51]. Value addition of hides is through suspension drying (10\%) and wet salting (90\%) while for skins, sun drying (70\%) is the major method of preservation [17]. Hides are by far the highest export earner from livestock industry and the only products from Ugandan livestock which have been able to break into the world-wide export market. They are mostly exported to Europe. Hides are also used in the making of drums which are some of the traditional musical instruments in the country. Skins from goats and sheep are used as seats in the village homes and in shrines, the traditional worship places.

The head and the hoofs are roasted, cooked and eaten as food by people. The main by-product from chicken are feathers and chicken manure. Chicken feathers and droppings are usually disposed-off to the soil as manure. No value addition on these two by-products has been reported so far.

\subsubsection{Innovations for Wastes/By-Products in Fish Sector}

The by-products in the fish factories include frames, skins, guts, scales, fats, trimmings, fish maws and rejected fish from the processing line. Of these by-products, only fish guts and scales, which constitute $2 \%$ of the whole fish are discarded [21]. With exception of fish maws, which are usually dried or frozen and exported to Asia and Europe [19], the rest of the fish by-products are sold in the local market. This local market has saved a lot of money for the fish processors/factories which they should have spent on disposing them off. Fish frames and skins are mainly consumed in smoked form whereas trimmings are usually rolled into fish balls and then fried for people to eat while the fats are used for frying the fish balls.

\subsubsection{Innovation for By-Products in Forestry Sector}

According to [25], Portland cement and saw dust from plantation grown Pinus caribea of 22 to 25 years old can be mixed to make bricks out of the mixture. Their research revealed that the use of wood/cement composite bricks can reduce overall weight of the construction since their densities and weights are generally low. However, the research also revealed that these composite bricks did not qualify for use as high strength external construction materials since their strength is considerably low and their structural strength is affected by damp conditions. [52] conducted a study on the effect of particle size of a mixture of Kaolin and ball clay incorporated with wood sawdust on the thermal conductivity of fired bricks. The results showed that the thermal conductivity increases with decrease in particle size of Kaoline and ball clay, but decreases with increase in particle size of saw dust. [52] also carried an experiment on the effect of particle size of a mixture of ball clay, Kaolin and sawdust on the thermal diffusivity of ceramic bricks using and indirect method involving measurement 
of thermal conductivity, density and specific heat capacity. The study revealed that the co-efficient of thermal diffusivity increases decrease in particle size of kaolin and ball clay but decreases with increase in particle size of sawdust.

Sawdust is being used as feed in the Indigenous Micro-Organisms (IMO) technology [53]. The technology involves use of micro-organisms to hydrolyze cellulose in sawdust to edible sugars hence being used as feed to pigs. The liquid IMO culture is applied to sawdust while the pigs are being fed with the usual food. The micro-organisms then digest the cellulose in the sawdust and the pigs start eating the sawdust. As the micro-organisms continue to digest the cellulose in saw dust, the quality will require to be replenished as the pigs eat most of the litter. [53] noted that the technology has the following advantages: raising pigs with no smell, no flies and no cleaning. Ability to decompose organic compounds, catalysis of chemical processes in the soil, natural ecosystems to facilitate recovery and suppression of diseases by circulating naturally active materials.

\section{Proposed Value Addition Options for the Different Agricultural By-Products}

Uganda has many agricultural by-products and in significant volumes. However, value addition of most of them is still a challenge and so they end up being wasted or sold for low prices in raw form. Hence more innovations are still needed to have new and more valuable and environmentally friendly products generated from them. Hence this section therefore proposes some of these innovations.

According to [54], there are a number of value-added products that can be made from animals' by-products. First and foremost, bones can be used to produce soft tissue, in making buttons, knife handles, and bone meal, or mixed with pottery clay or used in refining sugar. Blood is used as a raw material in making adhesives and fertilizers. Glycerin can be utilized in several of industrial uses such as production of nitroglycerin, ointment bases, solvents, vehicles for medicine, preservatives for food, plasticizers and humectants. Intestines can make sausage casings, musical strings and surgical ligatures. Hides and skins can be processed into leather and the different leather products like belts, bags and shoes. Feathers from poultry can be utilized for insulation, as decorative items, making pillows and animal feed among others.

Fish oil is the major dietary source of long chain omega-3 polyunsaturated fatty acids and so can be utilized to enrich different food products [55]. The modern diet has inadequate omega fatty acids and so inclusion of sleek fish in the diet a few times each week is suggested [56]. They also note that fish pepsin can be used as a rennet substitute in cheese production. Fish by-products are raw materials in production of enzymes which after purification are alternatives to the conventional lime-sulphide dehairing process [57].

According to [58], saw dust together with wood can make wood-plastic composites which have some advantages over the conventional mineral materials. 
They are lighter in comparison to fiber glass and less abrasive with their consumption being 1,170,000 tons per annum in the United States. The commonest type of wood-plastic composites are produced by mixing flour and plastics to produce a material that can be processed just like a plastic but has the best features of wood and plastics.

\section{Conclusion}

This study reviewed innovations in value addition of agricultural by-products in Uganda and found out that even though a number of innovations have been cited, more research needs to be done to get more products from these by-products especially from the fish, animal and the forestry subsector. In the present agricultural sector where the globe has become a single market, agriculture must be competitive with value addition of both the main products and the by-products. If our agriculture has got to be competitive, we will have to find alternative methods of adding value to our different agricultural by-products so that we can take full advantage of both the local and international markets. Value addition of agricultural by-products will reduce the high post-harvest losses, increase industrialization, employment generation, more products to offer to the market and foreign exchange earning among other benefits. Besides these benefits, value addition of agricultural by-products will reduce environment degradation as a result of poor waste disposal into the environment. Therefore, it's time for us as a country to focus on new product development from these by-products to make them more valuable and desirable to the market especially from the livestock by-products given their potential of being turned into a variety of high market value products that can be sold on both local and international markets.

\section{Conflicts of Interest}

The authors declare no conflicts of interest regarding the publication of this paper.

\section{References}

[1] MGLSD (2007) Strengthening Statistics for Planning. Ministry of Gender Labour and Social Development Sector Strategic Plan for Statistics (2006/7-2010/11). 2007-2011. Unpublished. https://www.ubos.org/onlinefiles/uploads/ubos/MGLSD\%20SSPS.pdf

[2] Sabiiti, E. (2011) Utilising Agricultural Waste to Enhance Food Security and Conserve the Environment. African Journal of Food, Agriculture, Nutrition and Development, 11, 1-9.

[3] Sabiiti, E., Bareeba, F., Drake, I., Ekbom, B., Kyamanywa, S., Lendin, S., Mugisha, J., Ottabong, E., Sabiiti, N., Sporndly, E. and T enywa, J. (2004) Urban Market Garbage: a Hidden Resource for Sustainable Urban/Per-Urban Agriculture. The Uganda Journal, 50, 102-109.

[4] Tumuhairwe, J.B., Tenywa, J.S., Otabbong, E. and Ledin, S. (2009) Comparison of Four Low-Technology Composting Methods for Market Crop Wastes. Waste Man- 
agement, 29, 2274-2281. https://doi.org/10.1016/j.wasman.2009.03.015

[5] Mwiganga, M. and Kansiime, F. (2005) The Impact of Mpererwe Landfill in Kampala-Uganda, on the Surrounding Environment. Physics and Chemistry of the Earth, 30, 744-750. https://doi.org/10.1016/j.pce.2005.08.016

[6] Ezcurra, I. Ortiz de Zarate, Vhan Dhin, P. and J.P. Lacaux, J.P. (2001) Cereal Waste Burning Pollution in the Town of Victoria (Northern Spain). Atmospheric Environment, 33, 1377-1386. https://doi.org/10.1016/S1352-2310(00)00393-9

[7] Helkar, P.B., Sahoo, A.K. and Patil, N.J. (2016) Review: Food Industry By products Used as a Functional Food Ingredients. International Journal of Waste Resources, 6 , 3.

[8] MEMD (2015) Biomass Technology in Uganda: The Unexploited Energy Potential BMAU Briefing Paper (5/15). Unpublished.

http://finance.go.ug/sites/default/files/publications/BMAU\%20Briefing\%20Paper\%2 05-15\%20\%20Biomass\%20Technology\%20in\%20Uganda.\%20The\%20Unexploited \%20Energy\%20Potential.pdf

[9] Miito, G.J. and Banadda, N. (2016) Waste to Energy Technologies for Solid Waste Management a Case Study of Uganda. Agricultural Engineering International: CIGR Journal, 18, 136-146.

[10] Kutty, C.K., SilvaI, P., Ntulanabo, F. and Kucel, S.B. (2003) Standalone Small Level Power Systems Based on Utilization of Agricultural Residue (Benecke System) Stand Alone Small Level Power Systems Based on Utilisation of Agricultural Residue ( Benecke System). Domestic Use of Energy Conference, April 2003.

[11] MTTI (2010) National Sugar Policy. A Frame Work for Enhancement of Competitiveness, Public-Private Partnerships, and Social Transformation. Ministry of Tourism, Trade and Industry.

http://mtic.go.ug/2016/index.php?/doc download/97-national-sugar-policy/

[12] Yadav, R.L. and Solomon, S. (2006) Potential of Developing Sugarcane by-Product Based Industries in India. Sugar Tech, 8, 104-111.

https://doi.org/10.1007/BF02943642

[13] Olupot, P.W., Candia, A. Menya, and Eand Walozi, R.(2016) Characterization of Rice Husk Varieties in Uganda for Biofuels and Their Techno-Economic Feasibility in Gasification. Chemical Engineering Research and Design, 107, 63-72. https://doi.org/10.1016/j.cherd.2015.11.010

[14] UBOS (2009) The National Livestock Census a Summary Report of the National Livestock, 2008 Census. Unpublished.

https://www.ubos.org/wp-content/uploads/publications/05 2019THE NATIONAL LIVESTOCK CENSUS REPORT 2008.pdf

[15] Mapiye, C., Chimonyo, M., Muchenje, V., Dzama, K., Marufu, M.C. and Raats, J.G. (2007) Potential for Value-Addition of Nguni Cattle Products in the Communal Areas of South Africa: A Review. African Journal Agricultural Research, 2, 488-495.

[16] Okaka, D., Kayima, J. and Otim, G. (2013) Design of Biogas Plant for Rural Households in Uganda (Case Study: Apac District). Second International Conference on Advances in Engineering and Technology, 544-550.

[17] UIA (2010) Leather Sector Profile. https://www.ugandainvest.go.ug/uia/images/Download Center/SECTOR PROFILE /Leather Sector Profile.pdf

[18] FAO (2010) Poultry Waste Management in Developing Countries. http://www.fao.org/3/al715e/al715e00.pdf 
[19] Husken, S.M.C. and Kabahenda, M.K. (2009) A Review of Low-Value Fish Products Marketed in the Lake Victoria Region. http://pubs.iclarm.net/wfcms/file/SF0959SID/Programme\%20Coordinator/Project \%20Report\%201974\%20-\%208Dec09.pdf

[20] Gumisiriza, R., Mshandete, A.M., Thomas, M.S., Kansiime, F. and. Kivaisi, A.K. (2009) Nile Perch Fish Processing Waste along Lake Victoria in East Africa : Auditing and Characterization. African Journal of Environmental Science and Technolo$g y, 3,13-20$.

[21] Odongkara, K., Kyangwa, M., Wegoye, J., Nyapendi, A. and Jawoko, R. (2003) Globalisation and Fish Utilisation and Marketing Study; The Fish by-Product Sub-Sector and Livelihoods in Uganda.

https://assets.publishing.service.gov.uk/media/57a08d01e5274a31e00015b0/R8112d. pdf

[22] Charles, O.A. (2014) Woody Forest Products Utilization and Rural Area Transformation in Eastern Uganda: A Case of Nabitende Township, Iganga District. Journal of Environmental Science, Taxonomy and Food Technology, 8, 124-132. https://doi.org/10.9790/2402-0893124132

[23] MWE (2016) State of of Uganda's Forestry. https://www.mwe.go.ug/sites/default/files/State of Uganda's Forestry-2015.pdf

[24] NFA (2017) Land Cover Trends in Uganda. https://www.mwe.go.ug/sites/default/files/library/Land\%20Cover\%20Trends\%20in \%20Uganda-JTR\%202017.pdf

[25] Zziwa, A., Kizito, S., Banana, A.Y., Kaboggoza, J.R.S., Kambugu, R.K. and Seremba, O.E. (2006) Production of Composite Bricks from Sawdust Using Portland Cement as a Binder. Uganda Journal of Agricultural Sciences, 12, 38-44.

[26] Amaya, A., Medero, N., Tancredi, N., Silva, H. and Deiana, C. (2007) Activated Carbon Briquettes from Biomass Materials. Bioresource Technology, 98, 1635-1641. https://doi.org/10.1016/j.biortech.2006.05.049

[27] Katimbo, A., Kiggundu, N., Kizito, S., Kivumbi, H.B. and Tumutegyereize, P. (2014) Potential of Densification of Mango Waste and Effect of Binders on Produced Briquettes. Agricultural Engineering International: CIGR Journal, 16, 146-155.

[28] Okello, C., Kasisira, L.L. and Okure, M. (2011) Optimizing Densification Condition of Coffee Husks Briquettes Using Response Surface Methodology. Proceedings Second International Conference on Advances in Engineering Technology Entebbe, Uganda.

[29] Guillermo, M., Retablo, A., Fovissste, C., Miguel, G. and Jalisco, D. (2004) An Easy Way to Determine the Working Parameters of the Mechanical Densification Process. Agricultural Engineering International: The CIGR Journal of Scientific Research and Development, 6, 1-18.

[30] Roothaert, R.L., Ssalongo, S. and Fulgensio, J. (2011) The Rakai Chicken Model: An Approach that Has Improved Fortunes for Ugandan Farmers. International Journal of Agricultural Sustainability, 9, 222-231. https://doi.org/10.3763/ijas.2010.0563

[31] Bukenya, H. (2013) Effectiveness of Briquettes as an Alternative Energy Source for Households.

http://energyincubator.org/wp-content/uploads/2015/09/Effectiveness-of-briquettes -as-an-alternative-cooking-fuel-in-Uganda.pdf

[32] Lugojja, F. (2017) Cotton and Its by-Products in Uganda. https://unctad.org/en/PublicationsLibrary/sucmisc2017d4 en.pdf 
[33] Allen, P. and Padayachee, N. (2011) Agricultural Use of Filter Cake from the Tongaat Hulett Sugar Refinery. Proceedings of South African Technology Association, 84, 510-515.

[34] Cornelissen, G., Martinnsen, V., Shitumbanuma, V., Alling, V., Breedveld, G., Rutherford, D. and Mulder, J. (2013) Biochar Effect on Maize Yield and Soil Characteristics in Five Conservative Farming Sites in Zambia. Agronomy, 3, 256-274. https://doi.org/10.3390/agronomy3020256

[35] Kochsiek, A.E. and Knops, J.M.H. (2012) Maize Cellulosic Biofuels: Soil Carbon Loss Can Be a Hidden Cost of Residue Removal. GCB Bioenergy, 4, 229-233. https://doi.org/10.1111/j.1757-1707.2011.01123.x

[36] Okello, C., Pindozzi, S., Faugno, S. and Boccia, L. (2013) Development of Bioenergy Technologies in Uganda: A Review of Progress. Renewable and Sustainable Energy Reviews, 18, 55-63. https://doi.org/10.1016/j.rser.2012.10.004

[37] Panwar, N.L., R. Kothari, R. and Tyagi, V.V. (2012) Thermo Chemical Conversion of Biomass-Eco Friendly Energy Routes. Renewable and Sustainable Energy Reviews, 16, 1801-1816. https://doi.org/10.1016/j.rser.2012.01.024

[38] Verheijen, F., Jeffery, S., Bastos, A.C., Van Der Velde, M. and Diafas, I. (2010) Biochar Application to Soils: A Critical Review of Effects on Soil Properties, Processes and Functions.

[39] Ndhlovu, M. and Banadda, N. (2017) Determination of Sufficiency of Crop Residue for Biochar Application. African Journal of Agriculture, 4, 254-262.

[40] Bagamba, F., Kikulwe, E., Tushemereirwe, W.K., Nhambeki, D., Muhangi, J., Kagezi, G.H., Ragama, P.E. and Eden-Green, S. (2006) Awareness of Banana Bacterial Wilt Control in Uganda: 1. Farmers' Perspective. African Crop Science Journal, 14, 157-164. https://doi.org/10.4314/acsj.v14i2.27923

[41] Bardiya, N., Somayaji, D. and Khanna, S. (1996) Biomethanation of Banana Peel and Pineapple Waste. Bioresiurce Technology, 58, 73-76.

https://doi.org/10.1016/S0960-8524(96)00107-1

[42] Tumutegyereize, P., Muranga, F.I., Kawongolo, J. and Nabugoomu, F. (2011) Optimization of Biogas Production from Banana Peels : Effect of Particle size on Methane Yield. African Journal of Biotechnology, 10, 18243-18251. https://doi.org/10.5897/AJB11.2442

[43] Omulo, G., Willett, S., Seay, J., Banadda, N., Kabenge, I. and Zziwa, A. (2017) Characterization of Slow Pyrolysis Wood Vinegar and Tar from Banana Wastes Biomass as Potential Organic Pesticides. Journal of Sustainable Development, 10, 81-92. https://doi.org/10.5539/jsd.v10n3p81

[44] Sekaluvu, S., Tumutegyereize, P. and Kiggundu, N. (2014) Investigation of Factors Affecting the Production and Properties of Maize Cob-Particleboards. Waste and Biomass Valorization, 5, 27-32. https://doi.org/10.1007/s12649-013-9228-9

[45] Delivand, M.K., Barz, M., Gheewala, S.H. and Sajjakulnukit, B. (2011) Economic Feasibility Assessment of Rice Straw Utilization for Electricity Generating through Combustion in Thailand. Applied Energy, 88, 3651-2658. https://doi.org/10.1016/j.apenergy.2011.04.001

[46] Kakudidi, E.K. (2007) A Study of Plant Materials Used for House Construction around Kibale National Park, Western Uganda. African Journal of Ecology, 45, 22-27. https://doi.org/10.1111/j.1365-2028.2007.00733.x

[47] Zake, J., Tenywa, J.S. and Kabi, F. (2010) Improvement of Manure Management for Crop Production in Central Uganda. Journal of Sustainable Agriculture, 34, 
595-617. https://doi.org/10.1080/10440046.2010.493368

[48] Muhereza, I., Pritchard, D. and Murray-Prior, R. (2014) Utilisation of Cattle Manure and Inorganic Fertiliser for Food Production in Central Uganda. Journal of Agriculture and Environment for International Development, 108, 135-151.

[49] Whalen, J.K., Chang, C., Clayton, G.W. and Carefoot, J.P. (2000) Cattle Manure Amendments Can Increase the $\mathrm{pH}$ of Acid Soils. Soil Science Society of American Journal, 64, 962-966. https://doi.org/10.2136/sssaj2000.643962x

[50] Rajendran, K., Aslanzadeh, S. and Taherzadeh, M.J. (2012) Household Biogas Digesters-A Review. Energies, 5, 2911-2942. https://doi.org/10.3390/en5082911

[51] Kasisira, L.L. and Muyiiya, N.D. (2009) Assessment of the Effect of Mixing Pig and Cow Dung on Biogas Yield. Agricultural Engineering International: CIGR Journal, 11.

[52] Bwayo, E. and Obwoya, S.K. (2014) Thermal Conductivity of Insulation Brick Developed From Sawdust and Selected Uganda Clays. International Journal of Research in Engineering and Technology, 3, 282-285.

[53] Lagu, C., Andama, M., Lee, S., Park, M. and Ainomugisha, A. (2017) Prevalence and Intensity of Internal Parasites in Pigs under Indigenous Micro-Organism (IMO) and Conventional Piggery Farms, Greater Mbarara, Uganda. Livestock Research for Rural Development, 29, 1-11.

[54] Ockerman, H.W. and Hansen, C.L. (2000) Animal by-Product Processing. 2nd Edition, Ellis Horwood International Publisher in Science and Technology, London. https://doi.org/10.1201/9781482293920

[55] Kolanowski, W. and Laufenberg, G. (2006) Enrichment of Food Products with Polyunsaturated Fatty Acids by Fish Oil Addition. European Food Research and Technology, 222, 472-477. https://doi.org/10.1007/s00217-005-0089-8

[56] Datta, S. (2013) Value Added Fish Products. https://www.researchgate.net/publication/259345025 Value Added Fish Products

[57] Saranya, R., Prasanna, R., Jayapriya, J., Aravindhan, R. and Selvi, A.T. (2016) Value Addition o Fish Waste in the Leather Industry for Dehairing. Journal of Cleaner Production, 118, 179-186. https://doi.org/10.1016/j.jclepro.2015.12.103

[58] Shiroma, L., Paulo, S., Antonio, P. and Beraldo, L. (2008) Wood-Plastic Composite. Proceedings of the 51 st International Convention of Society of Wood Science and Technology, Concepcion, Chile, 10-12 November 2009. 